\title{
Correction to: Serum levels of miR-21-5p and miR-339-5p associate with occupational trichloroethylene hypersensitivity syndrome
}

Wei Liu ${ }^{1,2+}$, Jian Zheng ${ }^{1,3+}$, Xiaohu Ren ${ }^{1}$, Yuxuan Xie ${ }^{4}$, Dafeng Lin ${ }^{4}$, Peimao Li ${ }^{4}$, Yuan LV$^{3}$, Maggie Pui Man Hoi ${ }^{2}$, Yanfang Zhang ${ }^{4^{*}}$ and Jianjun Liu ${ }^{1,3^{*}}$

Correction to: J Occup Med Toxicol 16, 19 (2021)

https://doi.org/10.1186/s12995-021-00308-0

Following the publication of the original article [1], we were notified that the second and the fourth affiliation should be swapped. Descriptions for Figs. 1 and 2 have also been added.

The original article has been corrected.

\begin{abstract}
Author details
'Shenzhen Key Laboratory of Modern Toxicology, Shenzhen Medical Key Discipline of Health Toxicology (2020-2024), Shenzhen Center for Disease Control and Prevention, Shenzhen 518055, China. ${ }^{2}$ State Key Laboratory of Quality Research in Chinese Medicine, Institute of Chinese Medical Sciences, University of Macau, Macau, China. ${ }^{3}$ Key Laboratory of Molecular Epidemiology of Hunan Province, School of Medicine, Hunan Normal University, Changsha 410081, China. ${ }^{4}$ Shenzhen Prevention and Treatment Center for Occupational Diseases, Shenzhen 518020, China.
\end{abstract}

Published online: 11 August 2021

\section{Reference}

1. Liu W, et al. Serum levels of miR-21-5p and miR-339-5p associate with occupational trichloroethylene hypersensitivity syndrome. J Occup Med Toxicol. 2021;16:19. https://doi.org/10.1186/s12995-021-00308-0.

The original article can be found online at https://doi.org/10.1186/s12995021-00308-0.

*Correspondence: junii8@126.com; 13923431511@139.com

+Wei Liu and Jian Zheng contributed equally to this work.

'Shenzhen Key Laboratory of Modern Toxicology, Shenzhen Medical Key Discipline of Health Toxicology (2020-2024), Shenzhen Center for Disease Control and Prevention, Shenzhen 518055, China

${ }^{4}$ Shenzhen Prevention and Treatment Center for Occupational Diseases, Shenzhen 518020, China

Full list of author information is available at the end of the article

(c) The Author(s). 2021 Open Access This article is licensed under a Creative Commons Attribution 4.0 International License, which permits use, sharing, adaptation, distribution and reproduction in any medium or format, as long as you give appropriate credit to the original author(s) and the source, provide a link to the Creative Commons licence, and indicate if changes were made. The images or other third party material in this article are included in the article's Creative Commons licence, unless indicated otherwise in a credit line to the material. If material is not included in the article's Creative Commons licence and your intended use is not permitted by statutory regulation or exceeds the permitted use, you will need to obtain permission directly from the copyright holder. To view a copy of this licence, visit http://creativecommons.org/licenses/by/4.0/. The Creative Commons Public Domain Dedication waiver (http://creativecommons.org/publicdomain/zero/1.0/) applies to the data made available in this article, unless otherwise stated in a credit line to the data. 